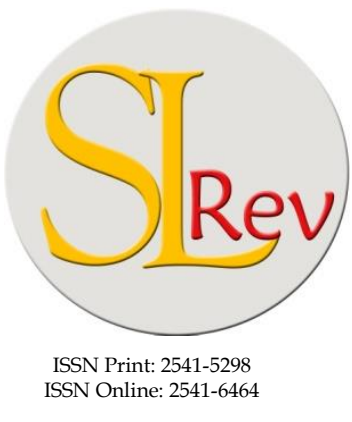

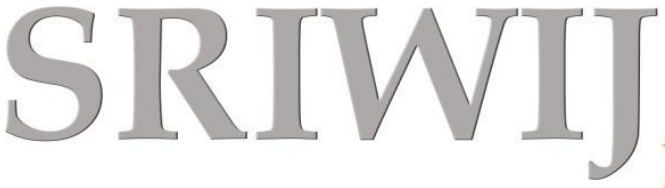
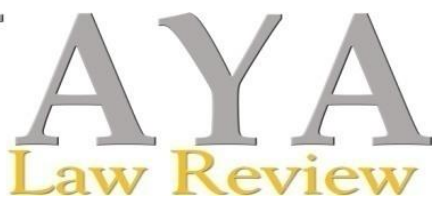

Editorial Office: Faculty of Law, Sriwijaya University

Jalan Srijaya Negara, Palembang, South Sumatra 30139, Indonesia.

Phone: +62711-580063Fax: +62711-581179

E-mail: sriwijayalawreview@ unsri.ac.id | sriwijayalawreview@gmail.com

Website: http://journal.fh.unsri.ac.id/index.php/sriwijayalawreview

\title{
The Qualified Effects Doctrine in the Extraterritorial of Competition Law Application: An Indonesia Perspective
}

\author{
Sukarmi, ${ }^{a}$ Hassan Qaqaya, ${ }^{b}$ Fransiska A. Susanto, ${ }^{a}$ and Rika Kurniaty ${ }^{{ }^{*}}$ \\ a* Corresponding Author. Department of International Law- Faculty of Law, Universitas Brawijaya, Malang, In- \\ donesia.E-mail: rika_kurniaty@ub.ac.id \\ b Melbourne Law School, University of Melbourne, Melbourne, Australia. E-mail: \\ hasaan.qaqaya@unimelb.edu.au
}

\begin{tabular}{|c|c|}
\hline Article & bstract \\
\hline $\begin{array}{l}\text { Effects Doctrine, Extra- } \\
\text { territorial Principle, } \\
\text { Competition Law, Indo- } \\
\text { nesian Practice } \\
\text { Article History } \\
\text { Received: Jan 27, 2021; } \\
\text { Reviewed: Jul 13, 2021; } \\
\text { Accepted: Jul 28, 2021; } \\
\text { Published: Jul 31, 2021. } \\
\text { DOI: } \\
\text { 10.28946/slrev.Vol5.Iss2. } \\
\text { 1050pp192-204 }\end{array}$ & $\begin{array}{l}\text { The use of extraterritorial jurisdiction of competition law, based on the } \\
\text { effect doctrine, has long been debated. This paper discusses the application } \\
\text { of extraterritorial jurisdiction to Indonesian competition law. Competition } \\
\text { law in Indonesia applies to any collusive or abusive behaviour that has a } \\
\text { necessary effect on the business and economy spheres, regardless of the } \\
\text { nationality or geographic location of the company or where the occurred } \\
\text { conduct. This study employs a normative juridical method to analyse legal } \\
\text { norms and principles. The approaches used include a statutory approach, a } \\
\text { comparative law approach, and a case approach. This study reveals that the } \\
\text { regulations concerning the prohibition of monopolistic practices and unfair } \\
\text { business competition have not explicitly regulated extraterritorial norms in } \\
\text { Indonesia. However, the Business Competition Supervisory Commission } \\
\text { makes legal breakthroughs by applying the extraterritorial principle to re- } \\
\text { solve the involvement of foreign business actors and impose penalties on } \\
\text { them. This article argues that Indonesia significantly needs to amend its } \\
\text { competition law and increase cooperation with other countries to enforce } \\
\text { the competition law. }\end{array}$ \\
\hline \multicolumn{2}{|c|}{$\begin{array}{l}\text { (C2021; This is an Open Access Research distributed under the term of the Creative Commons Attribution Li- } \\
\text { cense (https://Creativecommons.org/licences/by/4.0), which permits unrestricted use distribution, and reproduc- } \\
\text { tion in any medium, provided the original works is properly cited. }\end{array}$} \\
\hline
\end{tabular}

\section{INTRODUCTION}

In response to the free market and globalisation demands, in 1999, Indonesia has enacted Law No. 5 of 1999 concerning the Prohibition of Monopolistic Practices and Unfair Business Competition (hereafter, Indonesian Competition Law). Indonesia also established the Business Competition Supervisory Commission (KPPU) as the institution responsible for enforcing the regulation. Law No. 5/1999 aims to protect public interests and improve national economic efficiency. ${ }^{1}$ However, the development and advancement of technology and information and relations be-

1 A Syamsudin, “Komisi Pengawas Persaingan Usaha Bukan Peradilan?,” Kompas Daily, 2005. 
tween countries that have entered the free market and the regional economic integration under the ASEAN Economic Community (AEC) create challenges for the Indonesian government. This economic integration dramatically influences the development of business transactions that are carried out between businesses in the same jurisdiction, also in different jurisdictions and countries. $^{2}$ Indonesia faces problems in applying its Competition Law to foreign companies operating in Indonesia. ${ }^{3}$

Although since 1999 Indonesia has Competition Law, the implementation of these rules is that the Indonesian business competition law cannot be applied to companies that are not established in Indonesia. ${ }^{4}$ Article 1 number 5 of Indonesian Competition Law regulates the provisions of business actors that become the object are "business actors that are established and domiciled or as long as carrying out their activities within the territory of Indonesia". 5 The definition of the business actor in this law includes all types and forms of business, regardless of the nature of the legal entity, as long as the business actor carries out his business and/or economic activities in the Republic of Indonesia's jurisdiction. ${ }^{6}$

The Indonesian Business Competition Law provisions are different from the rules in various countries (i.e., America, European Union, Australia, Singapore, Korea, and Japan). In these countries, the subject of Business Competition Law is domestic business actors and applies to business actors abroad who impact their national economy. ${ }^{7}$ Even the American Antitrust Law can examine a person without looking at the offender's jurisdiction by using the principle of Extraterritoriality. ${ }^{8}$ This system difference is considered to have harmed Indonesia in international trade because Indonesia could be tried in another country. However, Indonesia could not prosecute foreign companies that violated Indonesian business competition provisions.

With the development of the economic activity that transcends borders between countries, Indonesian law should also overcome its problems. Implementation of a rule can be carried out without knowing any boundaries, including those related to business competition law enforcement. It is very likely that violations of the unfair business competition principle were not committed in Indonesia but significantly impacted domestically. One example of a conflict related to extraterritorial jurisdiction of Competition Law in recent decades includes the European Union (EU), the United States, and several other countries in Indonesia. The cases could refer to the

2 Manaek SM Pasaribu, "Challenges of Indonesian Competition Law and Some Suggestions for Improvement," ERIA Discussion Paper Series 04 (2016).

3 Rika Kurniaty, "The Features and Future Challenges of Indonesian Antimonopoly Policy: Lesson Learned From Japanese Experience," Procedia Enviromental Sciences 17 (2013): 999-1006.

4 Irma, A. D, Ikhwansyah,I, and Faisal, P "Cross Border Business Competition: Keabsahan Dan Hambatan Penerapan Prinsip Ekstateritorial Dalam Penegakan Hukum Persaingan Usaha Di Indonesia,” Jurnal Bina Mulia Hukum 3, no. 1 (2018).

5 Huzaini, M. D. P "Ekstrateritorialitas Penegakan Hukum Persaingan Usaha Sebuah Keniscayaan,” Hukum Online.com, 2017, https://www.hukumonline.com/berita/baca/lt598996a0c114b/ekstrateritorialitas-penegakanhukum-persaingan-usaha-sebuah-keniscayaan.

6 Sumaryo Suryokusumo, "Yurisdiksi Negara VS Yurisdiksi Ekstrateritorial," Indonesia Journal of International Law 2, no. 4 (2005).

7 Peter Behrens, "The Extraterritorial Reach of EU Competition Law Revisited: The 'Effects Doctrine' before the ECJ," Europa Kolleg Hamburg Institute for European Integration 3, no. 16 (2016).

8 David M. Gomez, Extraterritoriality in Competition Law and Globalization: Square Peg in a Round Hole? (University of Northumbria, 2005). 
case of Very Large Crude Carrier (VLCC) Pertamina, Telecommunication case of Temasek Holdings, and Toray case.

This paper discusses the effects doctrine in The Extraterritorial Jurisdiction of Business Competition Law. Unlike the existing study of extraterritorial principles, ${ }^{9}$ this article discusses how the effect doctrine could be "qualified" in extraterritorial competition law issues by studying the experience of the European Union case. The study is divided into seven sections. Following this introduction, the second section shows the methodology of the study. The third and fourth sections discuss state jurisdiction and the notion of extraterritorial. The fifth is the case study of the European Union. The sixth and seventh part elaborates on the legal breakthrough employed by KPPU and the revision discourse of Indonesian Competition Law. Finally, the last is the concluding remark.

\section{RESEARCH METHOD}

This study employs a normative juridical method to analyse legal norms and principles. The approaches used include a statutory approach, a comparative law approach, and a case approach. The data applied in this normative research is secondary data which is used as the primary data, including the 1945 Constitution, Law Number 5 of 1999 concerning the Prohibition of Monopolistic Practices and Unfair Business Competition, Law Number 36 Year 1999 concerning Telecommunications, Law Number 12 Year 2011 concerning the Establishment of Legislation, Regulation of the Supreme Court of the Republic of Indonesia Number: 03 of 2005 concerning Procedures for Filing Objections to the KPPU's Decision, KPPU Regulation Number 1 the Year 2010 concerning Case Handling Procedure. In addition to these legal materials, the research utilises data obtained from books, journals, and published scientific articles. The data obtained were then analysed by descriptive qualitative methods.

\section{ANALYSIS AND DISCUSSION Understanding State Jurisdiction}

Jurisdiction is generally defined as the state's power. This power is the means or action taken by a country to determine its national legislation and enforce the regulation. It also claims "persons, properties, conduct or the combination of the three". The jurisdiction of a country is limited in its national territory. Territoriality is the basis of a country's jurisdiction and is the foundation of a country's sovereignty. The state has unlimited legal sovereignty in every case that occurs in its territory, except with certain exceptions such as diplomatic agreements or the imposition of international law. ${ }^{10}$

The jurisdiction issue is closely related to law enforcement's problem in each country and directly connects with the sovereignty of a country. State jurisdiction means the power or authority of a State to declare and to enforce laws made by the state or the nation itself. More specifically, jurisdiction is the authority of the state to make and implement and enforce its national law with-

9 Asti Rachma Amalya, "Prinsip Ekstrateritorial Dalam Penegakan Hukum Persaingan Usaha," Jurnal Ilmiah Mandala Education 6, no. 1 (2020); and Darmawan, I. A., Ikhwansyah, I., \& Faisal, P. Cross-Border Business Competition: Keabsahan dan Hambatan Penerapan Prinsip Ekstrateritorial Dalam Penegakan Hukum Persaingan Usaha di Indonesia. Jurnal Bina Mulia Hukum, 3(1), (2018). 113-126

10 Jennifer A. Zerk, "Extraterritorial Jurisdiction: Lessons for the Business and Human Rights Sphere from Six Regulatory Areas,” Corporate Social Responsibility Initiative 59 (2010). 
in its territorial boundaries (according to national law). In addition, the state also has the authority to make and implement the enactment of the national law outside the boundaries of its territory, or better known as State jurisdiction based on international law. ${ }^{11}$

Extraterritorial jurisdiction regulates a country's legal ability to exercise its sovereignty/authority outside its territory as long as it concerns its territory. ${ }^{12}$ At the implementation level, applying the principle of extraterritorial jurisdiction encounters several obstacles, especially when dealing with jurisdictions in other countries. The principle of extraterritorial may not be fully implemented because a country cannot exercise its power in another country's territory, even though it has jurisdiction over particular legal interests there.

The application of the Republic of Indonesia's business competition jurisdiction to business actors domiciled in other countries is not explicitly regulated in Indonesian national law. Nevertheless, in the international community, there is the principle of Extraterritoriality in business competition law. Moreover, "Competition Law primarily involves direct assertions of extraterritorial jurisdiction over foreign actors and conduct".

\section{The Notion of Extraterritoriality Principle in Competition Law}

Under business competition law, in general, the use and formation of accountability can apply extraterritorially. For example, business actors may be subject to legal provisions for actions carried out by business entities as business actors, other business actors as economic entities even though one of the business entities is domiciled outside the country's territory. Extraterritorial jurisdiction is a condition where the state, through its authority, has complete power over its territory. However, there are exceptions where a state can exercise its jurisdiction in another country with some limitations.

The United States of America introduced extraterritorial jurisdiction in business competition law. Before the 1940s, countries in the world still applied "strict jurisdiction." Until 1945, there was the development of the start of the modern 'doctrinal effect' in the US antitrust jurisdictions. This development was marked by the United States vs Aluminium Co. of America ('Alcoa'). ${ }^{13}$ At Alcoa, the Second Circuit handled alleged anti-competitive cartels involving several foreign companies from Canada, Switzerland, Germany, and the United Kingdom.

The US government alleges that an independent Canadian company founded by Alcoa took over its foreign properties. Alcoa is considered to be participating in a foreign cartel that intends to set a quota on aluminium imported into the United States. Concerning the limitations that states typically comply with within exercising their powers, the US Judge argues that any state can impose obligations, even on persons not within its territory, for behaviour outside its borders that has consequences within its territory. Borders with other countries. Then, this obligation will usually be recognised by other countries.

Therefore, the United States applies the "effects doctrine" to legitimise its extraterritorial jurisdiction. This doctrine regulates the provisions, "any anti-competitive actor in the United States

11 Dkk Setyo Widagdo, Hukum Internasional Dalam Dinamika Hubungan Internasional (Malang: Universitas Brawijaya Press, 2019).

12 Michael Ristaniemi, "What Extraterritorial Application of Competition Law Means for MNCs," International In-House Counsel Journal 7, no. 28 (2014): 2.

13 Roger P. Alford, "The Extraterritorial Application of Antitrust Laws: The United States and European Community Approaches," Virginia Journal of International Law 33, no. 1 (1992): 7. 
of America could be charged with competition law in the United States of America law, if it is proven to have a monopoly or unfair business competition in its jurisdiction, whether by chance or planned". ${ }^{14}$ The regulation of business competition law is basically an obligation borne by the central government's jurisdiction, including legislative, executive, judicial jurisdictions that conceptually can be applied in an extraterritorial manner. However, in the context of its implementation, it is necessary to conduct further research on whether it has the potential to violate the autonomy of other countries or not.

The principle of territorial jurisdiction applies host country law to everyone who is in the country concerned territory. For example, business actors participating in Indonesia's business activities must comply with business competition regulations in Indonesia. ${ }^{15}$ This principle also applies to foreign shareholders in companies in Indonesia because the shares controlled are within the Republic of Indonesia's territory. This doctrine is a form of recognition of the holding company or holding company. The holding company and its subsidiaries have economic entities that are coordinated and connected.

One of the doctrines underlying this issue is the "Single Economic Entity Doctrine". The single Economic Entity Doctrine appears in business competition law in the European Union under the Christiani and Nielsen case. ${ }^{16}$ Initially, responsibility for a violation is only required to be carried out by companies that directly contract with the violation. However, in its development, the parent company can be held responsible for violations committed by its subsidiaries. The analogy used in this doctrine is the criminal justice system, where parents can be held accountable for their children's criminal acts. Likewise, in the relationship between the parent company/holding company and its subsidiaries.

This doctrine could make business competition law extraterritorial be applied. ${ }^{17}$ Business actors can be held accountable for actions taken by other business actors in one economic unit, even though business actors operate outside the country's business competition law jurisdiction. Therefore, business competition law can be extraterritorial countries can exercise their jurisdiction in other countries' territories with certain restrictions. ${ }^{18}$ Economically, single economic entities positively impact interrelated business actors, namely determining the same policies or management for every business actor associated with or with their subsidiaries. The hope is to create efficiency in running the business. However, on the opposite, a single economic entity can impact its subsidiaries, namely, not getting the freedom to determine the direction and policies of the company. The single economic entities are stated to have infringed the competition law and business spheres, even though the business entities are legally distinct, i.e., each has its legal entity.

14 Andrew D. Mitchell, "Broadening the Vision of Trade Liberalisation; International Competition Law and the WTO,” World Competition Law and Economics Review 24, no. 3 (2001): 343-65.

15 Widagdo, dkk. Hukum Internasional Dalam Dinamika Hubungan Internasional (Malang: Universitas Brawijaya Press, 2019).

16 Moisejevas Raimundas and Urbonas Denielius, "Problems Related to Determining of a Single Economic Entity under Competition Law," Yearbook of Antitrust and Regulatory Studies 10, no. 16 (2017): 107-26.

17 Okeoghene Odudu and David Bailey, "The Single Economic Entity Doctrine in EU Competition Law," Common Market Law Review 51, no. 6 (2014): 1721-57.

18 Susan Emmenegger, "Extraterritorial Economic Sanction and Their Foundation in International Law," Arizona Journal of International \& Comparative Law 33, no. 3 (2016). 
The single economic entity was first applied in the European Union in the case of dyestuff in 1972 and continues to grow in business competition, especially in the European Union. A company can be said to be a single economic entity seen from the ownership of shares owned must exceed $50 \%$ and become the majority share. However, if a company owns shares below 50\% but can control a subsidiary, the subsidiary does not have the freedom to run the company; it can be a single economic entity.

\section{Extraterritorial Principles in Other Regions: The Case of the European Union}

Although some studies on extraterritorial jurisdiction in Indonesia have been conducted, few studies look at how it is implemented in other countries. Therefore, in this article, we discuss the case of the EU. The EU Court of Justice in Wood Pulp I,8 cases, stated that:

"It should be observed that an infringement of Article 101, such as the conclusion of an agreement which has had the effect of restricting competition within the common market, consists of conduct made up of two elements, the formation of the agreement, decision or concerted practise and the implementation thereof. If the applicability of prohibitions laid down under competition law were made to depend on the place where the agreement, decision, or concerted practise was formed, the result would obviously be to give undertakings an easy means of evading those prohibitions. The decisive factor is, therefore, the place where it is implemented. The producers, in this case, implemented their pricing agreement within the common market. It is immaterial in that respect whether or not they had recourse to subsidiaries, agents, sub-agents, or branches within the community to make their contacts with purchasers within the community. Accordingly, the community's jurisdiction to apply its competition rules to such conduct is covered by the territoriality principle as universally recognised in public international law."

Nevertheless, "the European Commission states in the Effect on Trade Guidelines that both Article 101 and Article 102"19 apply to an agreement or practice irrespective of where the undertakings are located or where the agreement was concluded, provided that the agreement or practice is either implemented inside the EU, or produce effects inside the EU.

The above article is the basis for jurisdiction establishment, and it is referred to as the "qualified effects" doctrine. The qualified effects doctrine has been endorsed by the General Court of the European Union as an alternative basis for establishing jurisdiction to the "implementation" doctrine, at least concerning cases under Article 102 TFEU and the EU Merger Regulation. ${ }^{20}$

Note that jurisdiction can be established under the "qualified effects" doctrine based on the economic effects produced within a given territory; "implementation" of the agreement within that territory is not required. ${ }^{21}$ The effects doctrine means "that agreement, concerted practices, or decisions of associations of undertakings conceived abroad by foreign undertakings that have effects in certain states are brought under its jurisdiction". For example, in the Alcoa case, the Second Circuit Court of Appeals held that the competition rules might be applied on a foreign undertaking if the conduct of this undertaking has an immediate, substantial, and reasonably foreseeable effect on the commerce. The qualified effects doctrine is arguably more expansive

19 However, the European Commission states in the Effect on Trade Guidelines that both Article 101 and Article 102 TFEU applies to an agreement or practice irrespective of where the undertakings are located or where the agreement was concluded, provided that "the agreement or practice is either implemented inside the EU, or produce effects inside the EU.

20 for example, Case T - 286/09 Intel Corp., v European Commission, Judgment of the General Court of 12 June 2014 ( Intel ), citing the judgment of the General Court in Case T - 102/96 Gencor v European Commission [1999] ECR II - 753 (Gencor). The Intel judgment of the General Court has been appealed to the Court of Justice of the European Union

21 Bernadette Zelger, "EU Competition Law and Extraterritorial Jurisdiction: A Critical Analysis of The ECJ's Judgement in Interl," European Competition Journal 16, no. 2-3 (2020): 613-27. 
for establishing jurisdiction than the implementation doctrine. The General Court has held that qualified effects refer to the criteria of immediate, substantial and foreseeable effect. As such, the qualified effects doctrine may be an alternative avenue to seek to establish jurisdiction in third Countries.

The test and assessing whether the criteria are satisfied concerning the third country (where the products are sold) is likely to be highly fact-specific. For example, the fact that two companies had contacts with finished products purchasers in a third country, including negotiations regarding Component $\mathrm{X}$ pricing or that finished products are sold worldwide. The companies are unaware or indifferent to whether the finished products are sold in the third country and could assess implementation or qualified effects but may not be determinative either way.

\section{Legal Breakthrough by the Indonesian Business Competition Supervisory Commission}

This section will discuss the decision made by KPPU regarding cross-border businesses that impacted the Indonesian economic environment. Although the Indonesian Business Competition Law (Law No. 5 of 1999) does not regulate the principle of Extraterritoriality, Indonesia has decided on the case of business actors residing in other countries and established which is not based on Indonesian law. The principle of Extraterritoriality has been applied in 3 (three) cases, namely: ${ }^{22}$ The Case of Temasek in "Decision No. 07/KPPU-L/2007", the Very Large Crude Carrier (VLCC) case in Decision No. 07/KPPU-L/2004, and Toray Case in Decision No. 09/KPPU/Kep.3/I/2016.

The first decision is the Temasek case. The Commission issued the decision of Case Number: 07/KPPU-L/2007 submitted to these two business actors through a letter dated 26 April 2007. The KPPU Examining Team found strong indications of violating Article 27 letter (a) of Law Number 5/1999 committed by the Temasek Business Group. KPPU also found allegations of violations of Article 17 and Article 25 paragraph (1) letter b of Law Number 5/1999 committed by Telkomsel with a description of the findings as follows: ${ }^{23}$

“a) Temasek Holding (Private) Limited, through Singapore Telecommunication Ltd, Singapore Technologies Telemedia Pte.Ltd., Communication Ltd., Singapore Telecom Mobile Pte. Ltd. and Indonesia Communication Limited own 35\% shares in Telkomsel and 40.77\% in Indosat; b) Telkomsel and Indosat jointly control $89 \%$ market share or at least more than $50 \%$ market share in the cellular telecommunications services market throughout Indonesia; c) Based on economic data, it can be seen that Indosat's performance is not as good as the performance of other operators; d) Cross ownership owned by the Temasek Business Group against Telkomsel and Indosat has caused a reduction in competition between Telkomsel, which has market share largest, and Indosat, which has the second-largest market share in the cellular telecommunications services market in all regions of Indonesia; e) Ordered to Temasek Holdings, Pte. Ltd., together with Singapore Technologies Telemedia Pte. Ltd., STT Communications Ltd., Asia Mobile Holding Company Pte. Ltd., Asia Mobile Holdings Pte. Ltd., Indonesia Communication Limited, Indonesia Communication Pte. Ltd., Singapore Telecommunications Ltd., and Singapore Telecom Mobile Pte. Ltd. to stop the act of ownership of shares in Telkomsel and Indosat. It is done by releasing all of its share ownership in one of the companies, namely Telkomsel or Indosat, within a maximum period of 2 (two) years from the date this decision has permanent legal force."

In its decision, KPPU instructed the parties to decide on the company whose share ownership will be released and relinquish voting rights and the right to appoint directors and commissioners in one of the companies to be released, namely Telkomsel or Indosat, until the shares are released. KPPU also punishes each of them "to pay a fine of Rp. 25,000,000,000.00 (twenty-five

22 Kurnia Toha, "Extraterritorial Applicability of Indonesia Bussiness Competition Law As Efforts Dealing ASEAN Single Market," Jurnal Dinamika Hukum 15, no. 1 (2015): 21.

23 The KPPU Decision Number 07/KPPU-L/2007 
billion rupiahs), which must be deposited into the State Treasury as a payment of income for fines for violations in the field of business competition". In addition to this, the KPP has ordered Telkomsel to stop the practice of imposing high tariffs and reduce cellular service tariffs by at least $15 \%$ (fifteen per cent) of the applicable tariff. ${ }^{24}$

Besides, Indonesian law prohibits establishing several companies with the same business activities in the same relevant market if that results in the creation of a "dominant position" and "market control". ${ }^{25}$ In the Temasek case, the establishment of several companies with relatively similar business activities had an impact on the emergence of a dominant position. In the Temasek case, the company merging process has violated Article 27 because the established market shares have resulted in horizontal integration, which gives rise to control of the market. ${ }^{26}$

At the Court Appeal stage, the Temasek group argued that the Indonesian government (represented by the KPPU) was not authorised to examine because the companies included in the Temasek group were not established under Indonesian law. Besides, these companies do not operate directly in Indonesia. The KPPU rejected the Temasek group's appealed and stated that the Temasek group was a business entity that fulfilled the elements of Article 1 number 5 of Law No. 5 of 1999. It is worth noting that Article 1 adheres to the principle of a single economic entity. A subsidiary company does not have the independence to determine the direction of company policy in a parent-subsidiary relationship. The consequence is that business actors can be held accountable for other companies' actions in an economic entity.

The second case is Very Large Crude Carriers (VLCC) Pertamina Company. It was a famous case in Indonesia in the process of divesting two tankers. This case began in November 2002 when Pertamina ordered two VLCC tankers from Hyundai Heavy Industries in Ulsan, South Korea, for US\$ 65 million per unit. Nevertheless, lately, there have been financial difficulties. Pertamina then sold the two tankers for US\$ 184 million in April 2004. After being investigated by the KPPU, the appointment of a consultant in the sale was not through a tender. The Commission also considers the selling price to be lower and the potential loss of state revenue to reach Rp 180-504 billion. On March 3, 2005, KPPU stated that Pertamina had violated Law Number 5/1999 concerning the Prohibition of Monopolistic Practices and Unfair Business Competition. $^{27}$

In the VLCC case, the Supreme Court (MA) granted the cassation request from the Business Competition Supervisory Commission (KPPU) regarding the divestment (sale) of two massive crude carriers (VLCC) tankers owned by Pertamina. Members of the cassation panel of judges stated that the case had been decided on November 29. The cassation panel rejected Pertamina's objection, which was submitted to the Central Jakarta District Court. As a consequence of the decision, the decision at the Central Jakarta District Court was rejected. Thus, the decision on the cassation is the same as that of the Business Competition Supervisory Commission.

The Government of Indonesia decided the case because the tender was conducted in Indonesia and was considered to impact Indonesia up to 54 million USD. In the process of divesting the

\footnotetext{
24 Ningrum Natasya Sirait, "Indonesia's Experience with Its Competition Law and Challenges Ahead" (ASLI Inaugural Conference, 2008).

25 Nakagawa M, Challenges of Indonesian Competition Law and Some Suggestions for Improvement (The University of Oxford Centre for Competition Law and Policy, 2006).

26 Article 27 of Law Number 5 Year 1999.

27 The KPPU Decision No. 07/KPPU-L/2004
} 
two Pertamina Large Crude Carriers (VLCC) owned by PT Pertamina Indonesia, these foreign companies have been legally proven to have violated Article 22 of the business competition law. In this case, PT Pertamina, Tbk. and Goldman Sachs, Pte. has determined Frontline, Ltd. as the tender winner. Also, there was a violation of Article 19 letter (d) regarding discriminatory practices carried out jointly by PT Pertamina, Tbk., Goldman Sachs, Pte., Frontline, Ltd., and PT Equinox Shipping Company to Essar Shipping, Ltd. and Overseas Shipholding Group.

Against KPPU's Decision No. 07 / KPPU-L / 2004 on March 3, 2005, PT Pertamina Tbk., Goldman Sachs Pte., Frontline Ltd., and PT Equinox Shipping Company filed an appeal for objection in the Central Jakarta District Court. Based on the submission of objection legal remedies, then on May 25, 2005, the Panel of Judges through the Decision of the Central Jakarta District Court No.4 / KPPU / 2005 PN.JKT.PST granted the appeal for the objection. Then, based on the Decision of the Central Jakarta District Court, the KPPU submitted an appeal to the Supreme Court of Indonesia. On November 29, 2005, the Panel of Judges through the Republic of Indonesia's Supreme Court Decision No. 04K/ KPPU/ 2005 granted the KPPU's appeal request. With the issuance of the Supreme Court's Decision, under those decisions shown that Indonesia has implemented the Extraterritoriality principle in deciding several business cases against foreign companies in Indonesia.

The last case to be discussed in this article is the Toray case. The KPUU decided the Toray case involving a foreign company with Decision No. 17/KPPU M/2015 concerning the takeover of shares (acquisition) of the Wongjjin Company. In this decision, KPPU imposed sanctions on Toray Advanced Materials Korea Inc. (TAK), which is also a foreign legal entity that is not domiciled and domiciled in Indonesia. In this decision, the reported party was suspected of violating Law Number 5 of 1999, Article 29 in conjunction with Government Regulation Number 57 of 2010 , Article 6 .

In imposing the sentence, KPPU requires the reported party to have the following obligations: a) To declare that the Reported Party is legally and convincingly proven to have violated Law Number 5 of 1999, Article 29 in conjunction with Government Regulation Number 57 of 2010, Article 6; b) Punish the Reported Party to pay a fine of Rp. 2,000,000,000.00 (two billion rupiahs), which must be paid directly or through part of the Reported Party's business group located in Indonesia, to the State Treasury as payment for fines for violations in the field of business competition. c) Order the Reported Party to pay the fine, report, and submit a copy of the proof of payment of the fine to KPPU.

From the cases above, it is known that the Articles of Law No. 5 of 1999 does not explicitly regulate the relationship between the parent company or significant shareholder in the form of a foreign business entity and a company having direct activities in Indonesia. Article 1 (5), for example, regulates the range of application of the force territory. The law only applies to business actors domiciled or conducting business activities in the Republic of Indonesia's territory. The phrase that mentions that "which is established and domiciled in the jurisdiction of the Republic of Indonesia" indicates that the enactment of Law No.5 of 1999 adheres to the subjective territorial principle while the phrase "conducts business activities within the jurisdiction of the Republic of Indonesia" indicates the objective territorial principle.

Nevertheless, according to the provisions of Article 1, the scope of business actors is regulated accumulatively, which is limited to business entities that are established and domiciled or 
conducting business activities in the Republic of Indonesia's territory. The absence of regulations in Law No.5 of 1999 that explicitly stipulates the implementation of the extraterritorial principle will continue to create uncertainty in handling problems involving business actors who are not established and domiciled in Indonesia because legal certainty demands enforcement of the rules as stated in the provisions. ${ }^{28}$ Therefore, it is necessary to accommodate regulations with the extraterritorial doctrine to ensnare actions taken outside the territory of Indonesia but have an anticompetitive impact on the Indonesian market and affect the achievement of economic development goals in Indonesia. Improvements to Law no. 5 of 1999 are essential to explicitly regulate the scope of business actors holding companies in Indonesia. The draft law, Law No. 5 the Year 1999, shows the definition of the perpetrator.

\section{The Revision and State Cooperation Discourse}

The KPPU's Decision on the cases, as mentioned earlier, has raised challenges and public responses to encourage changes to Law No. 5 of 1999. The Academic Manuscript of the draft Revision of the Law states that the Indonesian government must review and perfect competition rules in Indonesia, particularly its implementation problems. An important issue related to the implementation of Law No. 5 of 1999 is the definition of business actors outside Indonesian jurisdiction.

In draft Act No. 5 of 1999, it appears that the definition of business has been expanded. The reason for the change in business actors' definition is that Indonesia has entered a free market society. The scope of the market and economic practices must involve the regional and international community. Therefore, regulatory instruments are needed that can accommodate these needs. The draft amendments to the law on the Prohibition of Monopolistic Practices and Unfair Business Competition specifically contain regulations on business actors established and domiciled outside the Republic of Indonesia's jurisdiction, wherein carrying out their anti-competitive practices have an impact on the Indonesian economy.

Article 1 (5) of Law Number 5 of 1999 only applies to business actors domiciled or conducting business activities in the Republic of Indonesia territory. The phrase which reads "established and domiciled in the jurisdiction of the Republic of Indonesia" indicates that the enactment of Law No.5 of 1999 adheres to the principle of subjective territoriality, while the phrase "conducting business within the jurisdiction of the Republic of Indonesia" indicates the objective territorial principle (ref). Thus, according to this article's provisions, business actors' scope is regulated cumulatively, limiting business entities established and domiciled or conducting business activities in the Republic of Indonesia.

KPPU's opinion is reflected in several cases related to business competition decided by KPPU. Since the establishment of KPPU in 2000, seven decisions were handed down by KPPU to foreign business entities that were not established, were not domiciled in Indonesia, and did not have branch offices or representative offices in Indonesia. ${ }^{29}$ KPPU applies the doctrine by reflecting on the experience in the European Union justification. The European Commission applied this principle in the Europemballage and Continental Can Commission in the 1973 case,

28 Syamsul Maarif, Merger Dalam Perspektif Hukum Persaingan Usaha (Jakarta: Degraf Publishing, 2010).

29 Verry Iskandar, "Akuisisi Saham Oleh Perusahaan Terafiliasi Dalam Perspektif Hukum Persaingan Usaha," Jurnal Persaingan Usaha 5 (2011). 
which was later strengthened by the European Supreme Court (European Court of Justice) and became jurisprudence subsequent business competition cases. According to Indonesia's legal system, it should be noted that it is not obliged to submit to the president as common law countries in the European Union but is subject to the laws and regulations (positive law) established by the legislative body.

Indonesian court decisions are only valid and empowered in the jurisdiction of Indonesia. Therefore, the process of law enforcement business competition and execution requires support in the form of bilateral or multilateral agreements with other countries. With the existence of agreements with other countries, it is expected that the confiscation of the reported assets will be more comfortable. Currently, KPPU has to find its list of assets reported that are domiciled abroad. With this international agreement, confiscating the reported assets can be carried out efficiently, considering that the audit process has a time limit. It can also cooperate in executing decisions that can be enforced actively and more efficiently.

Currently, KPPU has collaborated with several ASEAN countries and other business competition authorities, such as Japan Free Trade Commission (JFTC) and Korean Free Trade Commission (KFTC). However, this cooperation is only in the scope of notification, information exchange, and training. There has not been any cooperation in case handling and implementation of decisions.

\section{CONCLUSION}

In summary, Indonesian Law No. 5 of 1999 on Competition Law does not regulate extraterritorial jurisdiction for foreign companies. The Republic of Indonesia Supreme Court Regulation Number: 03 of 2005 (Concerning Procedures for Filing Legal Efforts Against KPPU's Decision) and KPPU Regulation Number 1 of 2010 (regarding Case Handling Procedures), no extraterritoriality clause in business competition law is explicitly found. This weak legal basis related to the coverage of legal subjects in Law No. 5 of 1999 will undoubtedly affect the execution of its decisions even though there have been decisions that have a permanent legal force that states that foreign business actors are proven to violate business competition rules. Without a solid legal basis, KPPU cannot carry out executions based on legal mechanisms. Indonesian court decisions are only valid and empowered in the jurisdiction of Indonesia. The process of law enforcement business competition and execution requires supporting bilateral or multilateral cooperation with other countries to efficiently and effectively execute.

\section{REFERENCES}

Alford, Roger P. "The Extraterritorial Application of Antitrust Laws: The United States and European Community Approaches." Virginia Journal of International Law 33, no. 1 (1992): 7.

Amalya, Asti Rachma. "Prinsip Ekstrateritorial Dalam Penegakan Hukum Persaingan Usaha." Jurnal Ilmiah Mandala Education 6, no. 1 (2020).

Behrens, Peter. "The Extraterritorial Reach of EU Competition Law Revisited: The 'Effects Doctrine' before the ECJ." Europa Kolleg Hamburg Institute for European Intergration 3, no. 16 (2016).

Darmawan, Irma Ambarini, Isis Ikhwansyah, and Pupung Faisal. "Cross Border Business 
Competition: Keabsahan Dan Hambatan Penerapan Prinsip Ekstateritorial Dalam Penegakan Hukum Persaingan Usaha Di Indonesia." Jurnal Bina Mulia Hukum 3, no. 1 (2018).

Emmenegger, Susan. "Extraterritorial Economic Sanction and Their Foundation in International Law." Arizona Journal of International \& Comparative Law 33, no. 3 (2016).

Gomez, David M. Extraterritoriality in Competition Law and Globalization: Square Peg in a Round Hole? University of Northumbria, 2005.

Huzaini, M Dani Pratama. "Ekstrateritorialitas Penegakan Hukum Persaingan Usaha Sebuah Keniscayaan." Hukum Online.com, 2017. https://www.hukumonline.com/berita/baca/lt598996a0c114b/ekstrateritorialitaspenegakan-hukum-persaingan-usaha-sebuah-keniscayaan.

Iskandar, Verry. "Akuisisi Saham Oleh Perusahaan Terafiliasi Dalam Perspektif Hukum Persaingan Usaha." Jurnal Persaingan Usaha 5 (2011).

Kurniaty, Rika. "The Features and Future Challenges of Indonesian Antimonopoly Policy: Lesson Learned From Japanese Experience.” Procedia Environmental Sciences 17 (2013): 999-1006.

M, Nakagawa. Challenges of Indonesian Competition Law and Some Suggestions for Improvement. The University of Oxford Centre for Competition Law and Policy, 2006.

Maarif, Syamsul. Merger Dalam Perspektif Hukum Persaingan Usaha. Jakarta: Degraf Publishing, 2010.

Mitchell, Andrew D. "Broadening the Vision of Trade Liberalisation; International Competition Law and the WTO." World Competition Law and Economics Review 24, no. 3 (2001): 343-65.

Odudu, Okeoghene, and David Bailey. "The Single Economic Entity Doctrine in EU Competition Law.” Common Market Law Review 51, no. 6 (2014): 1721-57.

Pasaribu, Manaek SM. "Challenges of Indonesian Competition Law and Some Suggestions for Improvement." ERIA Discussion Paper Series 04 (2016).

Raimundas, Moisejevas, and Urbonas Denielius. "Problems Related to Determining of a Single Economic Entity under Competition Law." Yearbook of Antitrust and Regulatory Studies 10, no. 16 (2017): 107-26.

Ristaniemi, Michael. "What Extraterritorial Application of Competition Law Means for MNCs." International In-House Counsel Journal 7, no. 28 (2014): 2.

Setyo Widagdo, Dkk. Hukum Internasional Dalam Dinamika Hubungan Internasional. Malang: Universitas Brawijaya Press, 2019.

Sirait, Ningrum Natasya. "Indonesia's Experience with Its Competition Law and Challenges Ahead." 2008.

Suryokusumo, Sumaryo. "Yurisdiksi Negara VS Yurisdiksi Ekstrateritorial.” Indonesia Journal of International Law 2, no. 4 (2005).

Syamsudin, A. “Komisi Pengawas Persaingan Usaha Bukan Peradilan?” Kompas Daily, 2005.

Toha, Kurnia. "Extraterritorial Applicability of Indonesia Bussiness Competition Law As 
Efforts Dealing ASEAN Single Market.” Jurnal Dinamika Hukum 15, no. 1 (2015): 21.

Zelger, Bernadette. "EU Competition Law and Extraterritorial Jurisdiction: A Critical Analysis of The ECJ's Judgement in Interl." European Competition Journal 16, no. 2-3 (2020): 613-27.

Zerk, Jennifer A. "Extraterritorial Jurisdiction: Lessons for the Business and Human Rights Sphere from Six Regulatory Areas." Corporate Social Responsibility Initiative 59 (2010). 